\title{
Free movements of medical professionals: policy and planning
}

\author{
Prasobsri Ungthavorn \\ From 7th Postgraduate Forum on Health Systems and Policies \\ Phitsanulok, Thailand. 24-25 June 2013
}

The target for member countries of the Association of Southeast Asian Nations to implement the ASEAN Economic Community in 2015 has raised concerns on how the free movements of health professionals would come into practice. After the Declaration on the AEC Blueprint was signed by heads of the member states in 2008, the ministries of commerce met in Cha-am, Petchaburi, Thailand, in 2009, to proceed on the Mutual Recognition Arrangement (MRA) on medical professionals. Several joint coordinating committees have worked on further details for medicine, dentistry and nursing. So far, the implementation of roadmap to facilitate free mobility of healthcare professionals within ASEAN is progressing but reaches some consensus on minor points. Further discussions are needed.

Published: 29 January 2014

doi:10.1186/1471-2458-14-S1-14

Cite this article as: Ungthavorn: Free movements of medical

professionals: policy and planning. BMC Public Health 2014 14(Suppl 1):14.

Correspondence: prasobsriu@yahoo.com

The Medical Council of Thailand, Nonthaburi 11000, Thailand

Submit your next manuscript to BioMed Central and take full advantage of:

- Convenient online submission

- Thorough peer review

- No space constraints or color figure charges

- Immediate publication on acceptance

- Inclusion in PubMed, CAS, Scopus and Google Scholar

- Research which is freely available for redistribution 